\title{
Municipal Solid Waste Landfills Construction and Management-A Few Concerns
}

\author{
PV Sivapullaiah, BP Naveen ${ }^{\star}$ and TG Sitharam \\ Department of Civil Engineering, Indian Institute of Science, Bangalore, India
}

*Corresponding author: BP Naveen, Research Associate, Department of Civil Engineering, Geotechnical Division, Indian Institute of Science, Bangalore, Karnataka 560012, India, Tel: +919916232349; Fax: +91-80-23600404; E-mail: bp.naveen864@gmail.com

Received date: Mar 30, 2016, Accepted date: Apr 25, 2016, Published date: May 02, 2016

Copyright: (c) 2016 Sivapullaiah PV, et al. This is an open-access article distributed under the terms of the Creative Commons Attribution License, which permits unrestricted use, distribution, and reproduction in any medium, provided the original author and source are credited.

\begin{abstract}
In Bangalore city, one of the major problems is municipal solid management (MSW) due to ever increasing waste quantity along with its changing waste characteristics. Municipal solid waste includes non-hazardous waste generated in house, institutions, commercial and business establishments in an urban area. As city grow and produce more municipal solid waste and their waste collection systems become more efficient, due the environmental impact from dump site becomes increasingly intolerable. A report on waste management prepared for the Government of India (1998) by a sub-committee of the Supreme Court describes this as a serious situation. The municipal bodies in Bangalore have been unable to manage the rapid changes that have led to both increased waste quantities and changes in the waste composition this leading to an over-loading of the service. MSW rules do not permit to dump mixed waste in direct land filling and hence, the waste needs to be segregated in order to collect and reuse all recyclable and the organic matter needs to be stabilized. The generated and collected MSW needs to be processed/ treated with only non-biodegradable MSW and the rejects of the processing facility being dumped in landfill. Leachate emanating from solid waste deposited in landfill possess dissolved or an entrained environmentally harmful substances. Generally, environmental impacts and economic damages of poor leachate management practices on groundwater and receiving surface waters are not clearly understood. With this context, this study, the concept of leachate pollution index, a tool for quantifying the leachate pollution potential and water quality index for surrounding water bodies of Mavallipura landfill site in Bangalore has been applied. It has been found that the leachate generated from the Mavallipura landfill site has high contamination potential to the surrounding water bodies. The results revealed that quality of ground water resources in Mavallipura landfill is deteriorating largely, as a result of the poor practice of solid waste management. Hence, an effective remedial plan needs to be prepared for the sustainable water quality maintenance of the area.
\end{abstract}

Keywords: Leachate; Leachate pollution index; Landfill; Water quality index; Solid waste

\section{Introduction}

Solid Waste Management is a very complex common problem in both developing and developed countries. Improper waste management can generally lead to transmission of illnesses, direct risks to those who contact with garbage, indirect risks of proliferation of animals that are carriers of microorganisms, aesthetic deterioration, degradation of the natural landscape, water, soil and air pollution. Improper management in developing countries results in dirty public areas, waste recovery in the streets, dumping of garbage into streams and rivers, or open dumps leading to men, women and children wade through the waste subjecting all of them to all kinds of diseases and accidents. The problem is aggravating due to rapid population growth, industrial development and changing eating habits and wide spread use of disposable containers.

Bangalore is the capital of Karnataka state in the south of India and one of the fastest growing metropolis in south asia, with a population of about 10 million in 2015. Bangalore generates around 4500 tons of wasteper day at the rate of $500 \mathrm{gm} /$ capita/day, and most this is illegally dumped in the peri urban areas of the city. About $20 \mathrm{kms}$ north of Bangalore city, close to Yelahanka town and the Yelahanka air force base, there is a village called Mavallipura. With the approval of
Bangalore Mahanagar Palike, since May 2003 the everyday, about 200 truckloads of municipal solid waste from the northern ward of Bangalore are being disposed on 20 acres of open land belonging to Mr. Bylappa from Mavallipura. Due to open dumping, over the years all drinking waters sources in the vicinity have been adversely affected and contaminating the Arkavathy river. This river basin located in the Mavallipura landfill, is just $2.5 \mathrm{~km}$ away from the flow of river Arkavathi. It is also $5 \mathrm{~km}$ from the air base.

\section{Description of Mavallipura Landfill Site}

The landfill is situated at survey no.108, at Mavallipura village, Hesaragatta zone, Bangalore North, Karnataka state. The landfill site is located in the north of Bangalore, India at Latitude $13^{\circ} 50^{\prime}$ North, Longitude $77^{\circ} 36^{\prime}$ East in the state of Karnataka. This landfill site has been used as a processing site for the municipal solid waste generated from the Bangalore city. Bangalore receives the average annual rainfall of $978 \mathrm{~mm}$. Primary rainy seasons is from June to September and the secondary rainy season is from November to December. Mavallipura village is located about 20 Kilometer away from Bangalore. About 100 acres of land in and around the village are used for dumping Bangalore's municipal waste by the Bruhat Bangalore Mahanagara Palike (BBMP- Greater Bangalore Municipal Corporation) that began accepting waste from 2005. The landfill was operated by M/s Ramky Environmental Engineers opened in 2007 can sustain about 600 tonnes of waste. However, the BBMP has been sending almost 1,000 tonnes of 
garbage from Bangalore city every day. But it is only able to process 250 tonnes. Citizens around Mavalipura village demand that the landfill site must be stopped immediately as it is illegal and unscientifically managed, and thus it is now closed for landfilling.

A little soil cover ( $0.3 \mathrm{~m}$ thickness) has been applied historically, and MSW is deposited in an unscientific manner that has resulted in steep, unstable slopes, leachate accumulation within the MSW mass, and leachate runoff into nearby water bodies such as pond and opened well. Mavallipura landfill site is about 40.48 hectares located in Mavallipura village, of which approximately 35 acres is used for landfill. Figure 1 shows the Google map with area map of Mavallipura landfill dump site. The features of the site are given in Table 1 .

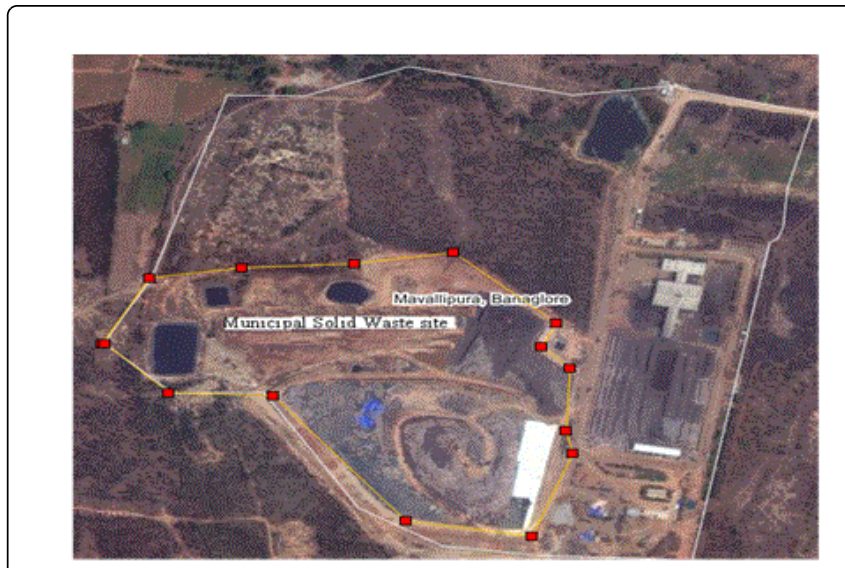

Figure 1: Area map of Mavallipura site.

\begin{tabular}{|c|c|}
\hline Features & Details \\
\hline Latitude and Longitude & $\begin{array}{l}\text { Latitude } 13^{\circ} 50^{\prime} \mathrm{m} \text { North } \\
\text { Longitude } 77^{\circ} 36^{\prime} \text { East }\end{array}$ \\
\hline Mean elevation of the site & Ranging from $51.38 \mathrm{~m}$ to $38.65 \mathrm{~m}$ above $\mathrm{MSL}$ \\
\hline Land area & 40.49 hectares \\
\hline Land use & Barren \\
\hline Nearest highway & $7.5 \mathrm{~km}$ away from the Nation highway No.7 connecting Mangalore to Chennai \\
\hline Access Road & Approach road to the site is well developed \\
\hline Water bodies and dams & Hessargatta water tank-5.5 km \\
\hline $\begin{array}{l}\text { Reserve forests, Ecological zones, Monuments, railway station, major } \\
\text { settlement }\end{array}$ & None within $10 \mathrm{~km}$ \\
\hline Socio economic & Agriculture based \\
\hline Minor settlement & Mavallipura village within $3 \mathrm{~km}$ \\
\hline Airport & $\begin{array}{l}\text { Bangalore airport more than } 30 \mathrm{~km} \\
\text { Deccan aviation centre at } 8 \mathrm{~km}\end{array}$ \\
\hline
\end{tabular}

Table 1: Mavallipura site Features [1].

\section{Plan of the Landfill}

The landfill has 3 cells at present. Cell 1 is completely filled and covered by a HDPE membrane. Cell 1 is spread around 5 acres. Cell 2 and 3 operational at present. A single liner system is used since this is not a hazardous waste landfill. The leachate collection systems are present outside the landfill (Figure 2).

The moisture content of the waste is around $40-50 \%$. The MSW waste is dumped in the landfill in layers of $1-3 \mathrm{~m}$. The limited waste lifts to approximately 2-3 meters had limited tipping fronts, were equipped with compaction machinery and bulldozers, and tracked waste accepted for landfilling. Waste pickers access to recyclable materials before solid waste arrived at the landfill site. There are leachate collection sumps for the collection of the leachate. HighDensity Polyethylene Pipe (HDPE) pipes are used for the collection of the leachate. It is laid at a slope of 1:2. These pipes are connected to the leachate collection sumps. The capacity of the sump is 2 lakh kilo litres. It is found that the leachate generated during the rainy season is 5 lakh per day. 30 kilo litres per day of leachate are taken to the leachate treatment facility and the liquid waste coming out of the treatment plant is taken to the solar evaporation ponds. The landfill provided five solar evaporation ponds, they are not scientific related to the depth, and is filled with leachate effluents. 


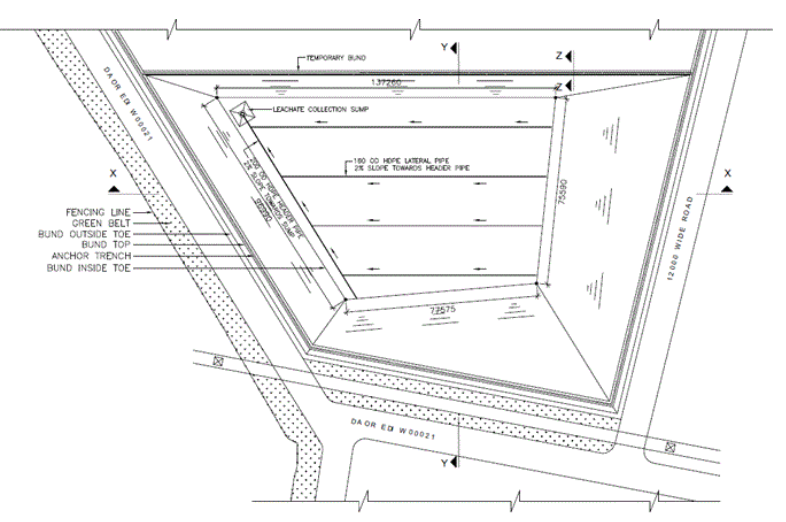

Figure 2: Mavallipura landfill Plan showing Leachate Network.

\section{Infrastructure Development for the Landfill}

In the Mavallipura landfill the following site infrastructure is provided:

Site entrance infrastructure included

1. Permanent, wide, entrance road with specific entry and exit lanes and gates.

2. Sufficient parking inside the entrance gate till the weighbridge to avoid queuing of vehicles outside the gate.

3. Proper direction signs and lighting at the gate.

4. Entrance area with a green belt of $20 \mathrm{~m}$ containing tree plantation.

5. All around the landfill site with lockable gates to prevent unauthorised access and a perimeter fencing of at least $2 \mathrm{~m}$ height.

6. Full time security guard at the site.

7. Two weigh bridge of $50 \mathrm{~T}$ capacity (entry and exit) with office.

8. Administrative office: $30 \mathrm{~m} \times 10 \mathrm{~m}$ building.

9. Site control office: $3 \mathrm{~m} \times 5 \mathrm{~m}$.

\section{Wastes Processing}

The wastes are brought to the site and dumped temporarily. The wastes undergo a number of processes before being taken to the landfill. Pre processing operations are carried out in order to separate the plastics and the recyclables. Windrow composting is done and the temperature is monitored. The detailed flowchart showing the operations is given in Figure 3.

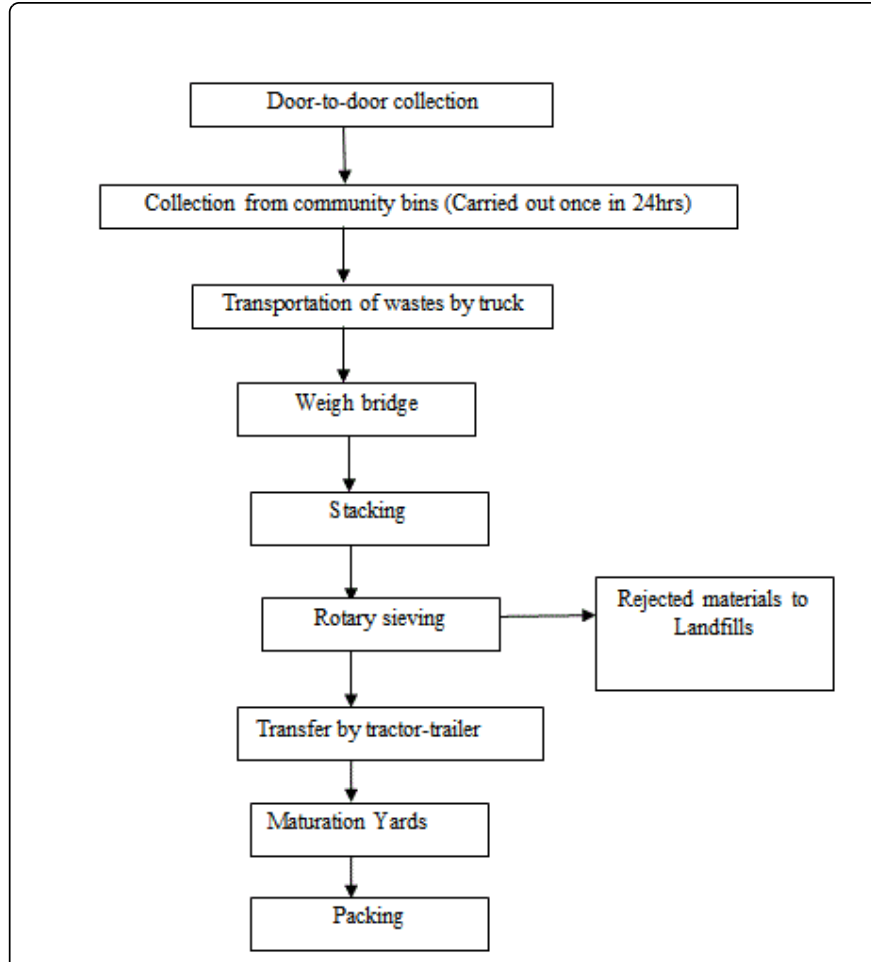

Figure 3: Schematic representation of the present practice of MSW in Bangalore.

\section{Windrow Composting}

Municipal Solid Waste (MSW) received at compost plant is a mixture of decomposable material with plastic, metal, glass, sand and other non-biodegradable material. MSW is first received in preprocessing area of the plant. In this phase, large size objects such as tires, cans, glass articles, metals are manually (hand picking) removed. Composting yard plan is shown in Figure 4.

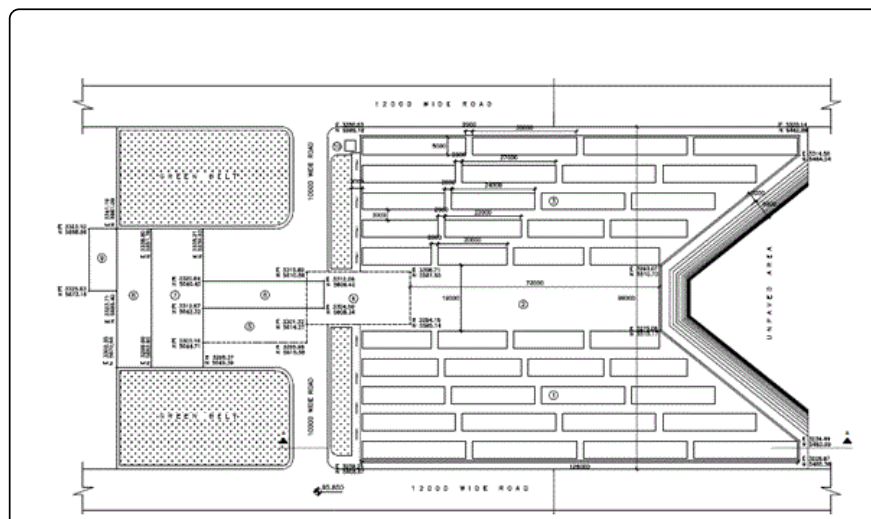

Figure 4: Composting yard plan.

This preprocessed MSW is then shifted to composting pad for decomposition by making windrows. Composting culture is sprayed on this waste and each windrow is turned frequently to maintain aerobic conditions for composting with maximum speed. Composted 
MSW is then shifted to coarse segregation area having mechanical arrangements to segregate the rejects like plastic, cloth, metals, glass of the size above $14 \mathrm{~mm}$ using rotary screen (trommel) of $35 \mathrm{~mm}$ and 15 $\mathrm{mm}$ sizes. Feeder, hopper and conveyer belts are provided with trommel for taking away rejects and semi-finished compost separately. Above semi-finished compost is then further shifted to curing section for further digestion. After curing, compost is shifted to refinement section which consists of vibratory screen or trommel of 4-6 mm size. Disposal of reject material (Rejects like gravels, sand, stones, glass, metal and other inert materials above $4 \mathrm{~mm}$ are separated in this section). This reject material goes to landfill.

\section{Landfill Design}

The landfill designer must address whether the unit will be above or below ground. Above ground disposal is particularly attractive for sites with shallow water tables. Above-ground landfills have the advantage that leachate can be drained by gravity, the facility is conspicuous and not easily forgotten or ignored, and construction of liner and drainage system components occurs on more or less level ground, which simplifies construction. Vertical expansions of existing facilities essentially constitute above-ground landfill.

Disposal units that are partly below ground have the advantage of allowing more waste to be disposed off in a given area, offer more efficient use of construction materials and potentially could allow for productive use of the land if the final surface is relatively flat. Several systems can be employed to control release of waste constituents. The primary objectives of control systems are:

(i) To minimize infiltration of water into waste through the cover or side walls of the facility.

(ii) To collect and remove gas and leachate, and

(iii) To minimize release of leachate to the subsurface.

The individual containment cells must be properly sized, and appropriate quantities of soil cover must be made available to minimize leachate formation and transport through the landfill.

\section{Landfill Capacity}

The perimeter of the dumpsite is $867 \mathrm{~m}$, and it encloses an area of $46,801 \mathrm{~m}^{2}$ or 4.68 hectares (Figure 5). The average height of the dumpsite from ground level is $7.5 \mathrm{~m}$ and the known average depth 6 $\mathrm{m}$. The total vertical depth of the site is therefore $6 \mathrm{~m}$, and the total volume of the waste approximately $280,800 \mathrm{~m}^{3}$. The average density of the wet waste is $0.685 \mathrm{~kg} / \mathrm{m}^{3}$. Based on the contour map, the average vertical depth of the landfill is $13.5 \mathrm{~m}$ and the total volume of the waste approximately $631,800 \mathrm{~m}^{3}$.

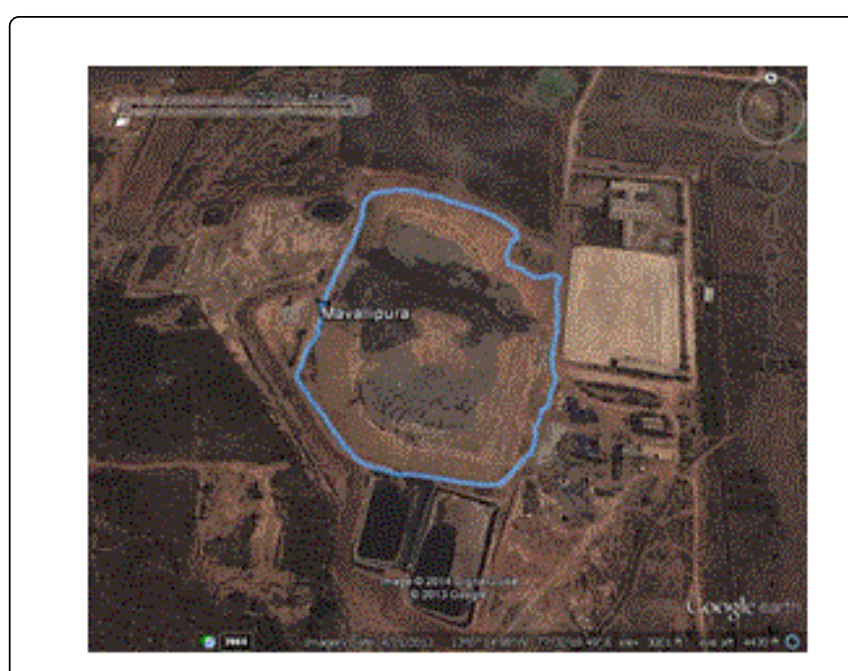

Figure 5: The perimeter of the dumpsite indicated on a google earth image of the site.

\section{Phased Operation}

Phase's operation consists of cells, lifts, daily cover, intermediate cover, liner and leachate collection facility, gas control facility and final cover over the sub-area.

Generally, each phase is typically designed for a period of 12 months. In each phases wastes are filled from the base to the final/ intermediate cover and capped within this period leaving a temporary unstored sloping face.

\section{Soil Cover Details}

The waste is simply brought and dumped in the landfill, spread in layers of about $0.3 \mathrm{~m}$ thickness, and compacted. Another layer of $0.3 \mathrm{~m}$ thickness is then placed on top of the previous layer and also compacted. Layering and compacting are repeated until a height of about $1.5 \mathrm{~m}$ is reached. At this point and the end of a working day, a cover of earth of about $0.3 \mathrm{~m}$ thickness is compacted on the top and side slopes of the compacted heap, which is called a soil cover (Figure $6)$.

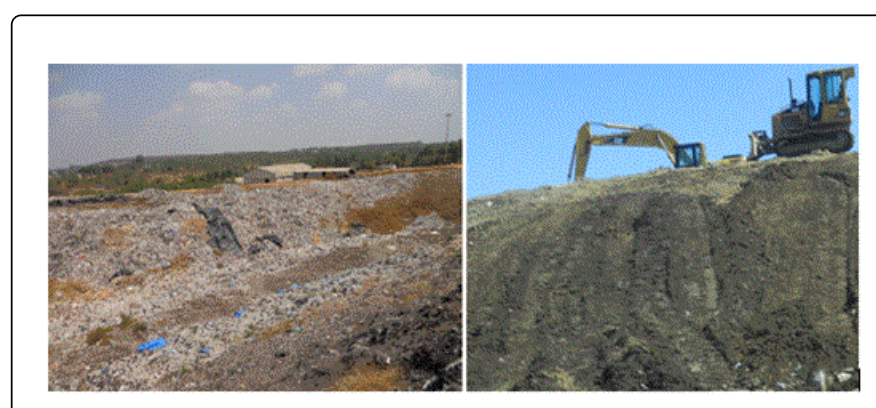

Figure 6: Typical construction procedures of soil cover.

The final cover for the landfill must minimize infiltration of surface water, prevent runoff contamination, and generally maintain the integrity of the hazardous waste landfill over the entire post closure 
period. Nearly all engineered cover systems (except perhaps those at arid sites) have a barrier layer. The barrier layer is generally either a single geomembrane, a layer of low-hydraulic-conductivity compacted soil, or a composite geomembrane-soil liner.

\section{Closure}

Proper planning greatly reduces the possibility of later adverse environmental problems. The goal should be to provide a site during the postclosure period that is environmentally acceptable.

\section{Liner system}

Liner system comprise of a combination of leachate drainage and collection layer and barrier as shown in Figure 7. A competent liner system should have low permeability, should be robust and durable and should be resistant to chemical attack, puncture and rupture.
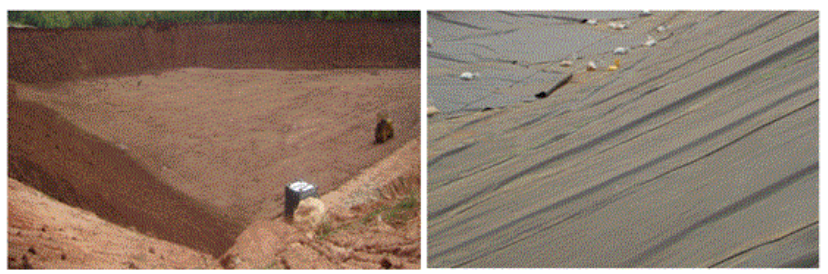

Figure 7: Liner system at base and side of landfill.

The clay liner thickness at base of Mavallipura landfill is $1 \mathrm{~m}$. The permeability of the clay liner is $<1 \times 10^{-9} \mathrm{~cm} / \mathrm{s}$. The clay liner is placed in layers not exceeding $300 \mathrm{~mm}$ and then compacted to the desired permeability and raised to a total thickness of $1 \mathrm{~m}$. The top of the clay liner, as well as the base of the landfill is effectively graded to attain a clear slope of $2 \%$ towards the leachate collection sump.

The liner system adopted at any landfill must satisfy the minimum requirements published by regulatory agencies (MOEF/CPCB). Generally it is recommended that for all MSW landfills the following single composite liner system be adopted as the minimum requirement.

1. A leachate drainage layer $30 \mathrm{~cm}$ thick made of granular soil having permeability greater than $10^{-2} \mathrm{~cm} / \mathrm{sec}$.

2. A protection layer of silty soil, $20 \mathrm{~cm}$ to $30 \mathrm{~cm}$ thick.

3. A geomembrane of thickness $1.5 \mathrm{~mm}$ or more.

4. A compacted clay barrier of $1 \mathrm{~m}$ thickness having permeability of less than $10^{-7} \mathrm{~cm} / \mathrm{sec}$

\section{Leachate Collection and Management}

For maintaining the effective leachate collection, the leachate collection pipes are embedded in a drainage media. The drainage media shall also be flow into the leachate collection sump. A geo-textile barrier is placed over the drainage media to ensures that the drainage media does not get choked and thus also ensure only the liquid percolation into the drainage.

Mainly landfill leachate is constituent of large amount of organic matter such as chemical oxygen demand and total organic carbon; as well as ammonia nitrogen, heavy metals like copper, zinc, iron, lead manganese etc, chlorinated organic and inorganic salts, which are a great threat to the surrounding soil, groundwater and even surface water $[2,3]$. All these factors make leachate treatment more difficult and complicated. The various methods are in use to treat the landfill leachate. Most of these methods are adopted for waste treatment processing and can be divided into major two categories namely: physical/chemical and biological treatment methods.

At present, in Mavallipura landfill leachate is treated by reverse osmosis process (Figure 8). This treatment is inexpensive system featuring disposable membranes that effectively capture the nutrients in leachate, separate out heavy metals and volatile organic compounds (VOCs), remove water from the landfill cell, and treat the water for reuse. The resulting byproducts make suitable fertilizers.

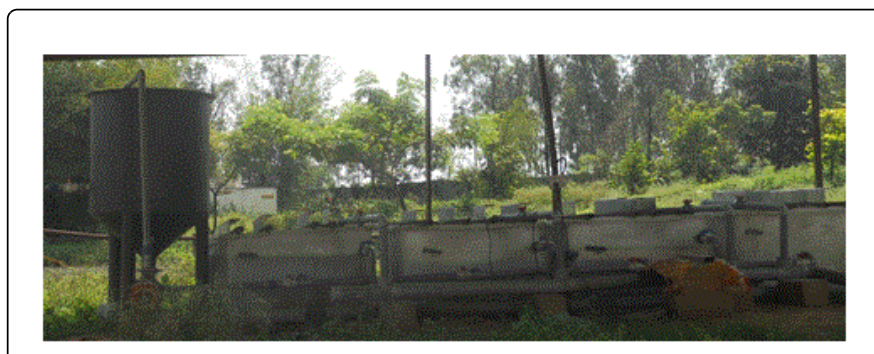

Figure 8: Reverse osmosis process carried out in landfill.

The system, comprised of membranes, pipes, pumps, treats leachate on site with minimal startup costs, energy consumption, odor and environmental damage.

\section{Landfill gas collection system}

Daily and intermittent soil covers shall be placed over the municipal solid wastes on a daily basis to ensure that odor generation is minimized. This soil covers also acts as a barrier thus providing for fire protection and effective movement of waste dumping trucks into the landfill. Before landfill capping, the vents and gas collection system shall be fitted to ensure that any gas generated in the landfill shall be effectively collected. The collected gas can be utilized for energy recovery.

\section{Surface water drainage system}

Collects and removes all surface runoff from the landfill site. Surface water drain: Adjacent to arterial road along periphery.

\section{Environmental monitoring systems}

The ground water monitoring system is present. There are 4 monitoring wells inside the site boundary which are monitored weekly and 6 monitoring wells situated away from the boundary which are monitored monthly. Ambient air quality monitoring is done monthly. Soil tests are done periodically.

\section{Water bound macadam road}

Main Access Road is $7 \mathrm{~m}$ wide, from main road to parking area after weigh-bridge and arterial Road is $3.5 \mathrm{~m}$ wide all along the periphery.

Water bound macadam road in landfill consists of following specifications are: 
Sub-base: The formation level of the road the first layer is called sublayer. Its material consists of a different quality than the base material. Its main objective is to protect the sub grade from the possibilities of getting damage during construction work.

Base: In this, material layer consists of soil. The base course consists of broken stone/ crushed stone which can be bound together with the help of stone dust in the presence of moisture. This base course consists of stone dust. The thickness of each compacted layer of WBM ranges from $10 \mathrm{~cm}$ to $7.5 \mathrm{~cm}$ depending on the size and the gradation of aggregate used. Its main objective is to transfer the traffic load uniformly on the soil.

Upper layer: This is final layer called surfacing, which is made by stone chips that are compacted by water (Figure 9). This gets broken during the traffic moves, and it can be easily repaired without removing the lower layers (Figure 10).

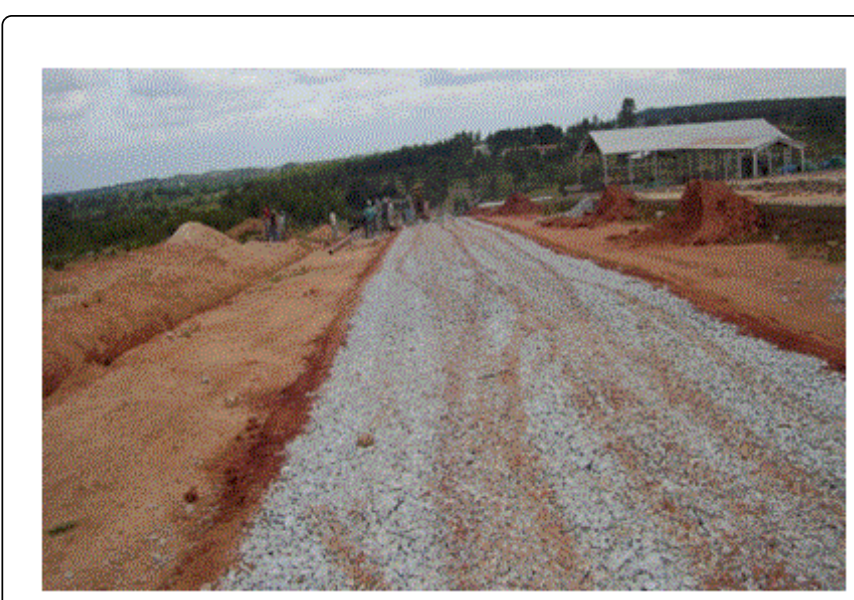

Figure 9: WBM road construction in landfill site.

\section{Influence of leachate migration on ground water quality}

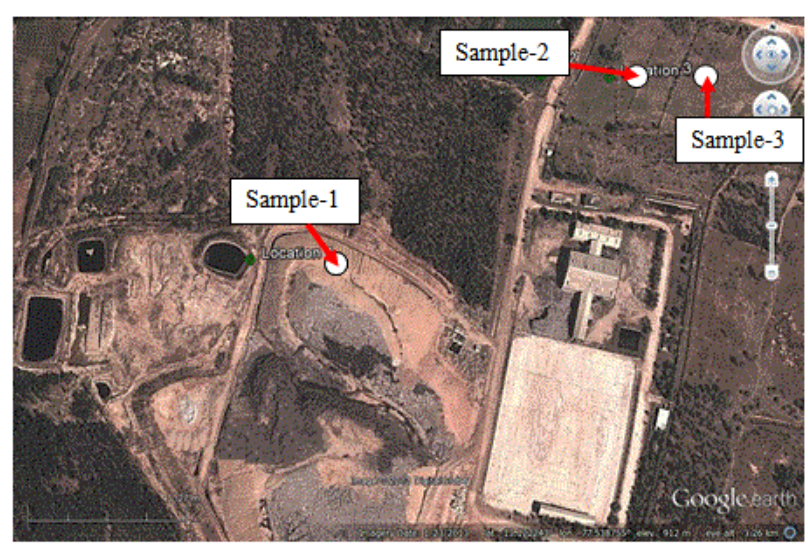

Figure 10: Sample locations points.

Figure 10 shows sample location points in landfill. The samples were collected in labeled clean bottles that were rinsed thrice before sample collection. The $\mathrm{pH}$ and electrical conductivity (EC) were recorded on site at the time of sampling with digital $\mathrm{pH}$ meter and digital EC meter, respectively. For the analysis of biological oxygen demand (BOD), 300 $\mathrm{ml}$ capacity BOD bottles were used for the collection of samples. For heavy metal analyses, samples were separately collected in pre-washed polyethylene containers of $100 \mathrm{ml}$ capacity and acidified (few drops of concentrated nitric acid were added to the leachate sample) onsite to avoid precipitation of metals. The samples were then transported in cooler boxes at a temperature below $5^{\circ} \mathrm{C}$ and transported immediately to the laboratory. A sample of leachate were stored in a refrigerator at $4^{\circ} \mathrm{C}$ before proceeding with the analysis and during laboratory analysis various ionic parameters were analysed. Later ion balance and quality assurance were also undertaken that is discussed in the subsequent sections of this chapter. The analysis is carried out according to standard methods for the examination of water and wastewater unless otherwise stated APHA [4].

\section{Results and Discussion}

Table 2 shows the results of the chemical characteristics of the leachate from Mavallipura landfill. As for metals, high concentrations of iron in the leachate, followed by zinc, nickel were observed. The concentrations of chromium, copper, cadmium and lead were low.

Leachate (sample-1); pond water (sample-2) and open well groundwater (sample-3) collected from different locations were analyzed for various physicochemical parameters. High concentration of organic and inorganic constituents were recorded that were beyond the permissible limits [5]. While, varied heavy metals levels were observed in the collected samples. Iron followed by zinc and nickel dominated among the metals analysed, wherein chromium, copper, cadmium and lead values were relatively lower. BOD5 to COD ratio revealed medium aged leachate samples ( 5 to 10 years). Total dissolved solids and electrical conductivity were found to be very high. Major anions like chloride is one of the most important parameters in assessing the water quality. The higher concentration of chlorides indicates a higher degree of organic pollution. The concentration of dissolved oxygen indicates the distribution of flora and fauna. Biochemical oxygen indicates the organic load in a water bodies. Higher BOD values are found in the polluted water.

The results revealed that quality of ground water resources in Mavallipura landfill is deteriorating day by day; largely as a consequence of the poor practice of solid waste management. Hence, an efficient precautionary plan is required for the sustainable management, which can be used as a guide for the regulation and supervision of ground water operations.

\section{Leachate Pollution Index Concept}

LPI provides an efficient method for evaluating the leachate contamination potential. The leachate pollution index (LPI) is formulated based on the Delphi technique. The LPI is a quantitative tool by which the leachate pollution data of the landfill sites can be reported uniformly. LPI formulation process involves selecting variables, deriving weights for the selected pollutant variables, formulating their sub indices curves, and finally aggregating the pollutant variables to arrive at the LPI [6] (Table 3).

LPI values were calculated for leachate sample of Mavallipura site. Table 3 show the calculations for LPI values of leachate samples in Mavallipura landfill site. The results indicate that the leachate sample has high LPI value and therefore, it has relatively more contamination potential. Mavallipura leachate sample can therefore pose threat to the 
Page 7 of 8

environment and human health and hence, measures and continuous monitoring must be ensured.

\begin{tabular}{|c|c|c|c|}
\hline Details & Leachate & Pond & Well \\
\hline & (Sample-1) & (Sample -2) & (Sample- 3) \\
\hline $\mathrm{pH}$ & 7.4 & 8.4 & 7.5 \\
\hline Conductivity, $\mu \mathrm{S} / \mathrm{cm}$ & 4120 & 2500 & 1362 \\
\hline TDS, mg/l & 2027 & 1447 & 703 \\
\hline COD, mg/l & 10400 & 1080 & 440 \\
\hline BOD3 , mg/l & 1500 & 105 & 3 \\
\hline Sulphate, mg/l & 40 & 10 & 7 \\
\hline Chloride, mg/l & 660 & 250 & 230 \\
\hline Calcium, mg/l & 400 & 0 & 320 \\
\hline Alkalinity, mg/l & 11200 & 2000 & 300 \\
\hline Iron, mg/l & 11.16 & 0.16 & 0.62 \\
\hline Copper, mg/l & 0.151 & $\mathrm{BDL}$ & BDL \\
\hline Silver, mg/l & 0.035 & 0.026 & 0.051 \\
\hline Chromium, mg/l & 0.021 & $\mathrm{BDL}$ & $\mathrm{BDL}$ \\
\hline Cadmium, mg/l & 0.035 & BDL & BDL \\
\hline Lead, mg/l & 0.3 & $\mathrm{BDL}$ & $\mathrm{BDL}$ \\
\hline Zinc, mg/l & 3 & 1 & 0.4 \\
\hline Nickel, mg/l & 1.339 & BDL & BDL \\
\hline Sodium, mg/l & 3710 & 1676 & 88 \\
\hline Potassium , mg/l & 1675 & 1078 & 46 \\
\hline Nitrate, mg/l & 22.36 & 0.18 & 1.09 \\
\hline Total Phosphorus, mg/l & 26.29 & 5.87 & 1.5 \\
\hline
\end{tabular}

Table 2: Leachate characteristic of Mavallipura landfill.

\begin{tabular}{|l|l|l|l|l|}
\hline Pollutant,mg/l & Sample-1 & $\mathbf{W i}$ & $\mathbf{P i}$ & $\mathbf{( P i W i )}$ \\
\hline $\mathrm{pH}$ & 7.4 & 0.055 & 5 & 0.275 \\
\hline TDS & 2027 & 0.05 & 8 & 0.4 \\
\hline BOD5 & 1500 & 0.061 & 55 & 3.36 \\
\hline COD & 10400 & 0.062 & 80 & 4.96 \\
\hline TKN & 2330 & 0.053 & 95 & 5.035 \\
\hline Ammonia Nitrogen & 1803 & 0.051 & 100 & 5.1 \\
\hline Iron & 11.16 & 0.044 & 5 & 0.22 \\
\hline Copper & 0.151 & 0.05 & 5 & 0.25 \\
\hline Nickel & 1.339 & 0.052 & 5 & 0.26 \\
\hline Zinc & 3 & 0.056 & 5 & 0.28 \\
\hline
\end{tabular}

\begin{tabular}{|l|l|l|l|l|}
\hline Lead & 0.3 & 0.063 & 5 & 0.31 \\
\hline Chromium & 0.021 & 0.064 & 10 & 0.64 \\
\hline Chlorides & 660 & 0.048 & 5.3 & 0.2544 \\
\hline Final LPI value 30.10 & \multicolumn{4}{|l}{} \\
\hline
\end{tabular}

Table 3: LPI for the landfill leachate.

\section{Ground Water Quality}

Water Quality Index is calculated based on important 13 parameters. By using standards of drinking water quality recommended by the BIS, ICMR, WHO. The unit weight arithmetic index was used from [7] for the calculation of WQI of the water body, Further; quality rating of sub index (qn) was calculated using the following expression.

$$
q n=100 X \frac{(\mathbf{V n}-\text { Viw })}{(\mathbf{S n}-\text { Viw })}
$$

qn $=$ Quality rating for the nth water quality parameter

$\mathrm{Vn}=$ Estimated value of the nth parameter at a given sampling station

$\mathrm{Sn}=$ Standard permissible value of the nth parameter.

Viw = Ideal value of nth parameter (i.e. zero for all parameters except the $\mathrm{pH}$ and Dissolved oxygen (7 and $14.6 \mathrm{mg} / \mathrm{L}$ respectively).

Water Quality Index was calculated by cumulative the quality rating with unit weight linearly.

$$
W Q I=100 X \frac{\boldsymbol{\Sigma} \mathbf{W n} X \mathbf{q n}}{\mathbf{\Sigma} \mathbf{W n}}
$$

Water quality index of the present water body is established from various important physicochemical parameters. The values of various physicochemical parameters for calculation of water quality index are presented in Table 4. Based on the Chatterjee [7] this water quality rating study clearly shows that, the status of the water body is eutrophic and it is unsuitable for drinking and also observed that the pollution load is relatively high. It can be inferred easily that the contamination of ground and surface water bodies near landfill site is due to migrating leachate. Again this may be due to seepage through improper barrier system laid or over follow or by both. In additional, the water bodies in the area are severely polluted and untreated leachate was found overflowing into storm water drains and also remained stagnant in open land.

Tables 4 show the calculations for WQI values of pond \& well water sample near the same landfill area.

\begin{tabular}{|l|l|l|l|l|l|}
\hline Parameters & $\begin{array}{l}\text { Unit } \\
\text { weight }\end{array}$ & Pond sample & WQI & Well sample & WQI \\
\hline $\mathrm{pH}$ & 0.219 & 8.4 & 20.44 & 7.5 & 7.3 \\
\hline $\mathrm{EC}$ & 0.371 & 2500 & 309.17 & 1362 & 168.4 \\
\hline TDS & 0.0037 & 1447 & 1.07 & 703 & 0.52 \\
\hline Total alkalinity & 0.0155 & 2000 & 25.83 & 300 & 3.875 \\
\hline Total hardness & 0.0062 & 1500 & 3.1 & 1000 & 2.067 \\
\hline TSS & 0.0037 & 1697 & 1.26 & 1384 & 1.02 \\
\hline
\end{tabular}


Page 8 of 8

\begin{tabular}{|l|l|l|l|l|l|}
\hline Calcium & 0.025 & 0 & 0 & 320 & 10.67 \\
\hline Magnesium & 0.061 & 1500 & 305 & 200 & 40.67 \\
\hline Chlorides & 0.0074 & 250 & 0.74 & 230 & 0.68 \\
\hline Nitrate & 0.0412 & 0.18 & 0.02 & 1.09 & 0.09 \\
\hline Sulphate & 0.01236 & 10 & 0.08 & 7 & 0.057 \\
\hline $\begin{array}{l}\text { Dissolved } \\
\text { oxygen }\end{array}$ & 0.3723 & 2.7 & 20.1 & 2.1 & 72.97 \\
\hline BOD & 0.3723 & 105 & 338.83 & 3 & 62.05 \\
\hline Total & & WQI $=678.94$ & & WQI $=370.37$ & \\
\hline
\end{tabular}

Table 4: WQI for the landfill pond \& well samples.

\section{Protection Measures}

Voluminous generation of leachate could be minimized by restricting water flow into the landfill through surface water diversion and reducing water accumulation in these landfill sites by frequent pumping in addition to with laying soil cover on a day to day basis. A low-permeability cover aids in restricting water infiltration into the landfill area. For suitable management of leachate effective containment of leachate with improved collection facilities are necessary [8].

Leachate produced during the landfill process has to be meticulously collected and treated with advanced microbial technologies as anaerobic baffled reactors, anaerobic filters and other biofilm based technologies. This also helps in checking the deterioration of groundwater resources from these MSW landfill sites.

As a part of upstream processing, it is equally important to ensure that only non-recyclable and inert waste is disposed, and no hazardous and bio-medical waste is entertained in landfills. Thus adequate waste segregation and utilization with bioprocesses like anaerobic digestion/ composting for organic waste treatment and management and incineration for biomedical waste can be followed before land filling. Furthermore adequate liners or barriers have to be installed in these landfill sites with proper capping for effective containment of the landfill wastes.

\section{Conclusions}

It has been concluded that leachate sample contain high concentration of organic and inorganic constituents. Heavy metals concentration was in trace amount as the waste in domestic in nature.

Leachate is found to have significantly high salinity and alkalinity as reflected in their values for conductivity, TDS, alkalinity and $\mathrm{pH}$. Hence the leachates were considered to contain significant loads of contaminats to pose threat to the underlying ground water aquifer.

Based on BOD5/COD ratio suggested that the Mavallipura landfill leachate is medium aged leachate.

The Mavallipura Landfill leachate migration to the soil and water resources poses a significant threat to the environment and public health.

High LPI values indicate that the leachates generated from landfill site are not stabilized, resulting in high concentrations of heavy metals in leachate.

The water quality rating study clearly shows that, the status of the water bodies is eutrophic and it is unsuitable for the human uses.

\section{References}

1. Ramachandra TV, Shruthi B (2006) Environmental Audit of Municipal Solid Waste Management, CEST Technical report-112, Energy \& Wetlands Research group, Cente for Ecological Sciences, IISc, submited to financial assistance the ministry of environment and forests government of India.

2. Robinson AH (2005) Landfill leachate treatment. Journal of Membrane Technology 6-12.

3. Welander U (1998) Characterisation and treat- ment of municipal landfill leachates, Thesis at Department of Biotechnology, Lund University.

4. APHA (1998) Standard Methods for Examination of Water and Waste water.

5. Erig HJ (1989) Quantity and Quality of MSW Landfill Leachate, Sardinia, Second International Landfill Sypmposium.

6. Kumar D, Alappat BJ (2003) A technique to quantify landfill leachate pollution.

7. Chatterjee C, Raziuddin M (2002) Determination of water quality index (WQI) of a degraded river in Asansol Industrial area, Raniganj, Burdwan, West Bengal, Nature. Environment and Pollution Technology 1: 49-59

8. Ministry of Environment and Forests (2005). 